\title{
Neck Pain Scale
}

National Cancer Institute

\section{Source}

National Cancer Institute. Neck Pain Scale. NCI Thesaurus. Code C136546.

A visual analogue scale designed to measure neck pain. 